\title{
The Role of Human Resources Management Practices Represented by Employee's Recruitment and Training and Motivating in Realization Competitive Advantage
}

\author{
Marwan M. Shammot ${ }^{1}$ \\ ${ }^{1}$ King Saud University, Kingdom of Saudi Arabia \\ Correspondence: Marwan M. Shammot, Associate Professor, Faculty of Administrative \& Humanities Sciences, \\ (Human ) College of Applied Studies \& Community Services, King Saud University, P. O. Box 28095, Kingdom \\ of Saudi Arabia. Tel: 966-5585-14191. E-mail: drmarwan965@yahoo.com
}

Received: January 6, 2014

Accepted: February 11, 2014

Online Published: March 26, 2014

doi: $10.5539 /$ ibr.v7n4p55

URL: http://dx.doi.org/10.5539/ibr.v7n4p55

\begin{abstract}
The present study identified role of human resource management in the realization of competitiveness in Industrial Organizations and has focused primarily on some important issues related to human resource management selection, training, motivating, attracting, employing, evaluating employees, and the setting of salaries, fees and rewards and the realization of competitiveness among business organizations. This paper has undergone for the evolution of HRM from past to present will be discussed in a theoretical concept. Then the role of human resources for organizations to gain competitive advantage and the innovations in HRM in the 21st century will be analyzed in a strategic view. Data was drawn from a sample of two industrial business organizations in the city of Amman. The study results showed that there is a significance relationship between the factors such as; raining, motivating, attracting, employing, evaluating employees, and the setting of salaries, fees and rewards of employees and workers and the realization of competitiveness among industrial business organizations. And this result is consistent with the outcome of previous studies.
\end{abstract}

Keywords: employees' recruitment, training, competitive advantage, industrial organizations, Jordan

\section{Introduction}

Since entering the new millennium, the world in general and the business world in particular became subjected to a spiral events and changes. Globalization and its related consequences of economic and cultural openness has imposed new burdens and challenges on business organizations, where businesses found themselves forced to adopt to these events and changes. Competition for example, became no longer local, and social mindedness shifted to become global mindedness, where the customer now wants to obtain the similarities of innovation between the domestic and foreign products (Nijssen et al., 2006), and this clearly means that competition became global and financial, causing organizations to search for what distinguishes it from others. In order to create and promote differences in organizational performance, who is difficult to be achieved by rivals, where the organizational strategy of the organization as a whole which consists of sub-strategies such as production and marketing strategy, HRM strategy must be interrelated with the general goals of the organization. In this regard, many researchers pointed out that organizations can gain competitive advantage by improving their resources from others. Hatch and Dyer (2004) reported that the resource-based view of the firm is more likely to explain sustained differences in firm performance by identifying differences in firm resources, their philosophy in this regard relies on, that organizations with valuable and rare resources may benefit in building competitive advantage. And, because the human capital is one of the organizational resources, this paper will focus on the role of human resources management practices in the fields of recruitment, training and motivation in achieving competitive advantage in Jordanian industrial organizations.

\subsection{Problem Statement and Questions}

The problem of this study can be formulated according to the following statement "Industrial organizations are able to acquire human capital, which has the talent; the ability and appropriate qualification are best placed to gain a competitive advantage in a time of fierce competition". This problem will be discussed through the following questions: 
1) What is the role of recruitment strategy in identifying recruitment methods and sources?

2) How HR department can exploit the recruit practice to attract the best applicants in terms of talent, competencies and qualifications to enhance the competitive advantage?

3) How can training programs and methods, to contribute to the achievement of competitive advantage in industrial organizations?

4) To what extent the flow of innovative ideas to build a competitive advantage influenced by the system of incentives?

\subsection{The Study Importance}

As mentioned in the introduction, organizations can make differences in their performance according to the differences in their sources from other organizations. This debate leads us to recognize the human capital as a valuable asset which can help organizations to achieve their goals including competitive advantage and superiority over competitors. The importance of this study lies in exploring methods that can help organizations to achieve their strategic goals. Where the greatest challenge facing organizations now in order to achieve their goals and maintain survival and continuity in a sharp competitive environment is the possession of human capital who has the ability and willingness to work in effective manner and who can provide innovative ideas to keep the organization safe from competitors. Hence, business world is witnessing now a race between organizations, whether local or global, to acquire the talent, skills, and distinctive competencies required from the human resource departments in various sectors to search seriously for such people. A variety of different sources can be used to attract personnel to work in a particular organization and to develop their skills, knowledge and abilities to contribute effectively towards achieving organizational goals (Huselid \& Becker, 2011), and in encouraging them to stay and work in the organization (Lockwood, 2007).

Also, this study meets a demand by research and academic institutions not only in Jordan, but also in the whole Arab World to enrich the Arabic library with recent studies on human capital and its value for both the employer and the customer. The main benefit of this research will help the Arab administration in the process of transition form a traditional and narrow view, which views the employees as a mere cost, to more comprehensive strategic horizon that views human capital as a precious asset.

\subsection{The Study Objectives}

This study aims to achieve the following objectives:

1) To discern the methods and sources of employees recruitment and the advantages and disadvantages of each method and source.

2) Identify the obstacles and challenges that are facing human resource management when recruiting the best applicants.

3) To illustrate the role of training methods in the development of employees performance and behavior to realize comptitve advantage. (competitive)

4) Come up with recommendations for the Jordanian industrial companies to help them to achieve competitive advantage through their human capital.

5) Explore if there is a linear relationship between the methods used to recruit staff in the study sample companies, and the training provided to the staff, and the system of incentives on the one hand, and achieve competitive advantage on the other.

\section{Methodology}

\subsection{Type of the Study}

The descriptive analytical approach was used to conduct this study, according to the quantitative paradigm.

\subsection{The Study Population and Sample}

The study population consists of the Jordanian pharmaceutical industrial companies, while the study sample consists of 100 employees working in the two companies; Al Hikma Pharmaceutical Company and ICCB Company.

\subsection{Data Collection Methods}

Secondary data was collected from books and researches and related previous studies by using Google Scholar, while primary data was collected through the distribution of a questionnaire to one hundred respondents who are working in the two companies in various levels; senior management, middle management and executive 
management in headquarters of the companies in Amman city.

\section{Hypotheses}

1) The first main hypothesis: $\mathbf{H A}_{\mathbf{1}}$ : There is statistically significant relationship between recruitment strategy and attracting best applicants.

2) The second main hypothesis: $\mathbf{H A}_{\mathbf{2}}$ : There is statistically significant relationship between the availability of talent, competencies and qualifications in the recruited employees and achieving competitive advantage.

3) The third main hypothesis: $\mathbf{H A}_{3}$ : There is statistically significant relationship between training programs and methods, and employee's development to create competitive advantage.

4) The fourth main hypothesis: $\mathbf{H A}_{\mathbf{4}}$ : There is statistically significant relationship between the incentives system in the company and the flow of innovative ideas to build a competitive advantage.

\subsection{The Study Model}

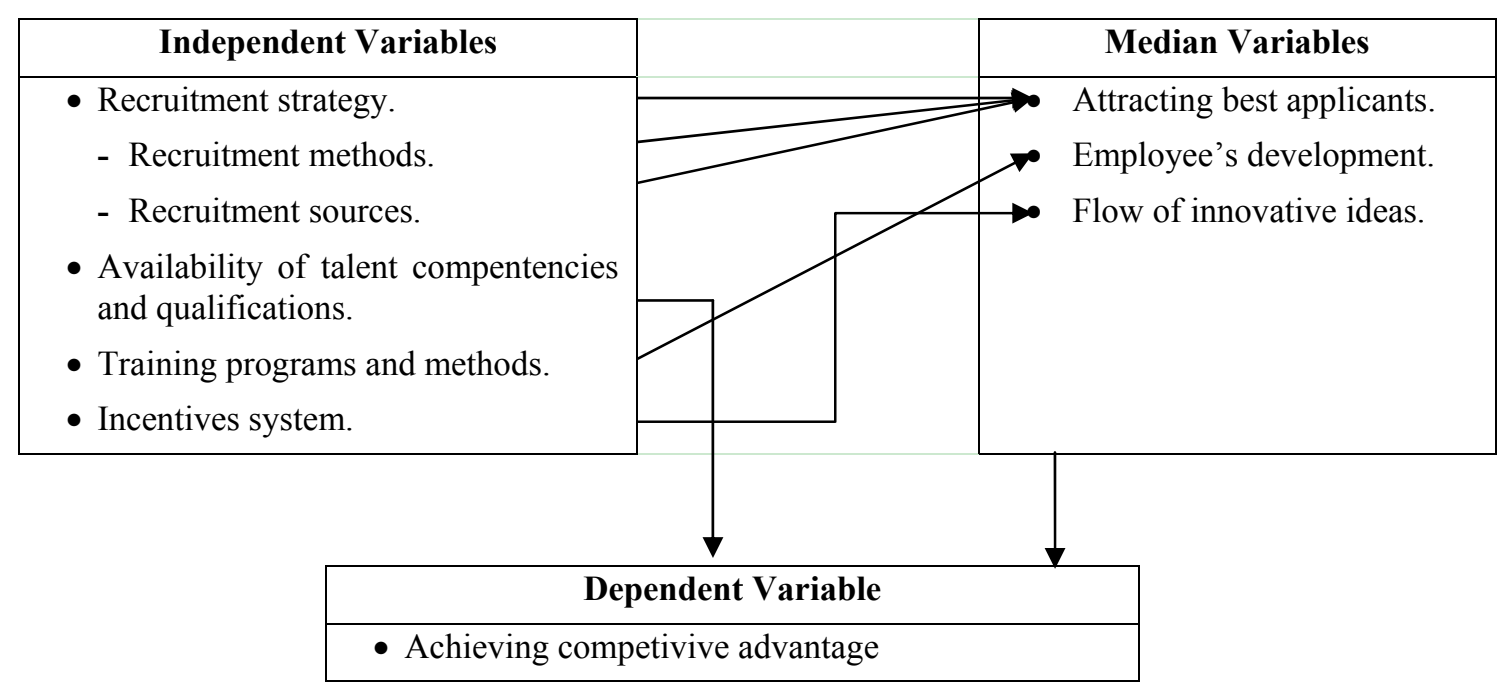

\section{Procedural Definitions}

\section{Competitive Advantage}

From the perspective of human resource management: The resource-based view of organizations provides an economic foundation for examining the role of HR in firm competitive advantage. Barney and Wright (1997) pointed out that there are three basic types of resources can provide competitive advantage, one of them is the human capital resources include things as the skills, judgment and intelligence of the firm's employees.

Talent: A person with special knowledge or ability who performs skillfully (vocabulary.com).

Recruitment Strategy: is the important document, which drives all recruitment related processes in the organization.

The effective recruitment strategy includes practices and activities aiming to employ the best candidates in terms of high behaviors and appropriate competences (Breaugh, 2008).

\section{Theoretical Background and Literature Review}

\section{-Employees recruitment:}

Many organizations fail to achieve their goals despite the possession of material resources, technology and other devices, such as equipment and financing. The reason for this failure in many cases may be due to the lack in such an organization of a human element which is capable of managing and investing these resources in an effective manner to achieve the goals of the organization. This is especially so in the creation of a competitive advantage for the organization which distinguishes it from others and preserves its existence and continuation. There are many studies in the literature that tackling the recruitment process from several view points. 
Historically, it could be argued that organizations believed that the most important goal of the recruitment process was to mobilize the largest possible number of employment seekers, which these organizations justified under the pretext of reducing the cost of recruitment (Wanous, 1992). Others, including Morse and Popovich (2009), saw that the traditional philosophy of recruitment was no more than the selling of the organization to outsiders. According to some researchers (Singh \& Finn, 2003), organizations have relied on traditional methods of recruiting employees, such as newspaper advertisements and employee referrals, which were based on the use of relatively low-tech approaches.

Today's business environment has forced organizations to change their perspectives about the recruitment process because of the influence of a number of constraints on recruitment activities. According to one piece of research (Cascio, 2003), reductions in the labor pool brought recruitment the greatest organizational attention. Another suggested reason (Thompson \& Aspinwall, 2009) is that the supply of qualified workers will never match the demand in the labor market. Moreover, it could be argued that this is especially true in some professions and disciplines, such as nursing, brokering in the financial markets, banking, certified public accounting, and education (Alhusary, 2006).

Some authors also pointed to a critical issue, which is the compatibility between the expectations of the applicant to occupy the post, in terms of the benefits that will be obtained by accepting the role, and what will actually be presented by the organization (Noe et al., 2008). It has also been highlighted that employees' requirements are changing: "Today's employees are becoming increasingly concerned with balancing their work and family lives, and they are said to highly value organizations that help them achieve this balance" (Thompson \& Aspinwall, 2009, p. 196).

These challenges and others have developed the concept of the recruitment process to one of an organizational strategy that includes those practices and activities carried out by the organization with the essential objective of describing the employees needed based on their skills, qualifications and abilities, and then attracting them in order to hire some of them (Breaugh \& Starke, 2000).

The most important characteristic of the recruitment process in this current era is that it has come to be aimed at putting the right person in the right place (Knowles et al., 2002). This goal was emphasized in the human resource literature. According to Croy and Duggan (2005), a company's most valued asset is its human capital, as it makes the difference between success and failure (Croy \& Duggan, 2005). Therefore, the recruitment process should be carried out using a systematic approach to achieve the recruitment goals successfully. The figure below shows a model for the organizational recruitment process:

\section{-A model of the organizational recruitment process:}

The figure shows that the first stage of the recruitment process is to identify targets. This stage is very important because without specifying clear objectives, the recruitment strategy will become meaningless (Rynes \& Barber, 1990). Some authors have indicated that recruitment must be managed through a systems approach (Carroll et al., 1999), and that the systematic procedure of recruitment can be performed in four stages, each of which constitutes a sub-system which interacts with the other three, and all interact with the recruitment process as a whole (Lewis et al., 1997). These stages have been defined as follows: an evaluation of the vacancy in terms of its need to be filled or not; the strategy development of whom, where and when to recruit; the preparation of the job's analysis; and the listing of the person specification (Carroll et al., 1999). The most important aspect in this phase, as stated in the human resource management literature, is that there must be a broad consensus between the HR strategy and the organizational strategy (Sheehan \& Scafidi, 2005). In spite of the integration of HRM activities within the organizational strategy, there is recognition that the strategic role of human resource management is still in the process of verification (Michelson \& Kramar, 2003). However, human resource management can impose a strategic role by harnessing its activities and practices to supporting the philosophy and strategy of the organization (Mayer, 2008). 


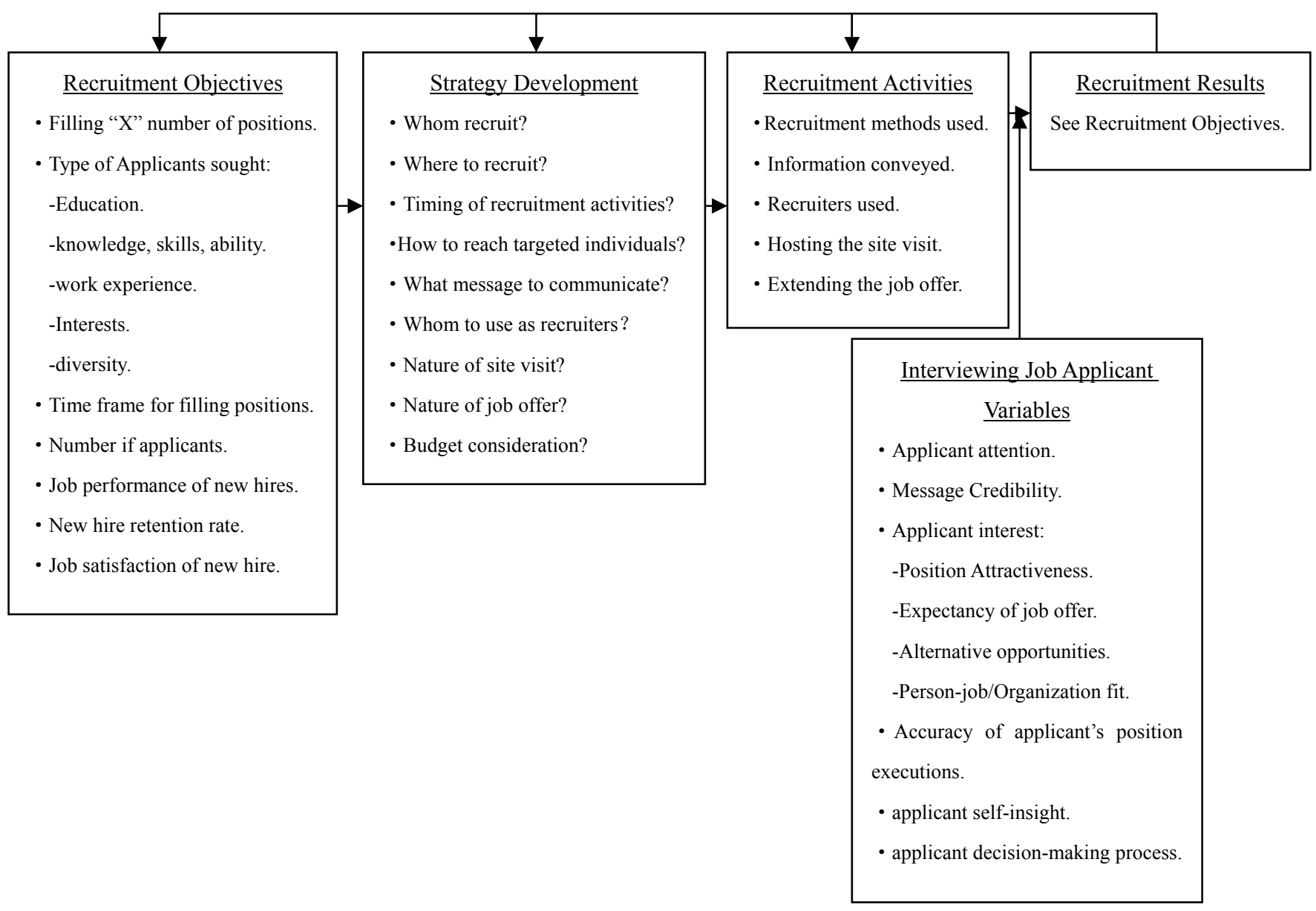

Figure 1. A model of the organizatonal recruitment proccess

Source: Breaugh ( 2008, p. 408)

\subsection{Best Practice in Employees' Recruitment}

In order to enhance its strategic role in organizational success, HRM must design the recruitment plan after close coordination with the other departments within the organization (Mayer, 2008). In this regard, some researchers have suggested that the plan should hold answers for questions such as: when to begin recruiting? What is the most appropriate text of the message to be delivered to the targeted applicants? Who are the recruiters? (Breaugh, 2008). Several studies are unanimous in including at this stage a focus on the targeted person, referred to by the term "Person Centred" (Alvesson \& Willmott, 2002). In this approach, the recruitment plan should align some key questions with the recruitment goals, most of these questions taking account of the intangible qualities within a person, such as values and attitudes, and whether they match the organization's beliefs (Townsend, 2007).

The most critical issue which should be taken into account is the cost of attracting and training new candidates (Zottoli \& Wanous, 2000). Therefore, in some cases, the recruitment allocation should be one of the largest items in the whole budget, especially if inexpensive resources, such as employee referrals, are not sufficient. Organizations incur considerable costs in recruiting and training new employees. Recruiting costs include advertising expenses, expenses connected with liaising with universities and other sources of prospective employees, the cost of the analysis of the applications to ensure that the qualifications and skills required are available, and then the salaries of those who are employed (Ehrenberg \& Smith, 2002). Thus, organizations must bear the following in mind:

Because of the cost of recruiting and training workers, employers must decide on an overall hiring strategy. Firms choosing a high wage strategy generate many applicants for each opening and can be selective, taking only trained, experienced workers. By paying high wages they avoid explicit and implicit costs of hiring the inexperience (Ehrenberg \& Smith, 2002, p. 99). 
It must be noted here that HR managers can reduce the cost of screening job applicants and, at the same time, acquire the best applicants. This is achieved as soon as they understand that there is a large gap between knowledge and practice (Ryan \& Tippins, 2004). This results in an understanding that performance indicators measure and compare what has been achieved as a result of the diligence of the individual, not the level of intelligence of that individual. Therefore, those organizations which screen job applicants for values have a higher employee performance than those which simply screen for intelligence (Delaney \& Huselid, 1996).

Good practice in recruitment requires HR managers to know that the use of certain recruitment tools can affect employee effectiveness and diversity. Employee referrals, for example, affect workforce diversity adversely (Sackett et al., 2001). Good practice in recruitment also requires knowledge of how technology can facilitate a task and reduce its cost.

\subsection{Recruitment Sources and Methods}

Before moving to discuss recruitment resources and how to use them, and examining the advantages and disadvantages of each, it should be noted that relatively recently literature has raised a very important topic which can be adopted by organizations in the process of attracting the best applicants. According to one study, organizations are tending now to publish their names, their philosophies and their attributes in order to attract recruits through a technique termed "Employer Branding" (Backhaus \& Tikoo, 2004). Employer branding was defined by Sullivan (2004) as a long-term strategy to make the organization the focus of employees and potential employees, and other relevant stakeholders (Sullivan, 2004). Employer branding contributes to the formation of a positive mental image for potential employees, and even on the level of society as a whole. This drives job seekers to work in a particular organization because they will reap a number of benefits in terms of a high salary and leave allowances, as well as social respect. Other researchers have defined the term "Employer Branding" as the total of an organization's efforts to communicate with current and potential employees (Lloyds, 2002).

In research aimed at developing and validating a scale to assess employer attractiveness (Berthon et al., 2005), the study population involved students at a large Australian university. The study sample consisted of 683 students divided into two samples, the first including 340, the second 343. The researchers used five factors to describe the underlying structure of employer attractiveness. Factor no. 1, "Interest value", evaluates the individual level of attraction to working in an organization because of the benefits and inducements offered by the organization, such as an exciting work environment, advanced work practices, and what employees would call their creations by producing innovative products and services.

Factor no. 2, "Social value", assesses the impact of a fun working environment, good relationships with peers in the workplace, and working as a team on employer attractiveness. Factor no. 3, "Economic value", assesses the extent to which an individual is attracted to an employer that pays a good salary. Factor no. 4, "Development value", assesses the impact of recognition, self-worth, confidence, and the career development programs provided by the employer on its attractiveness. Factor no. 5, "Application value", assesses the impact of providing an opportunity to employees to apply what they have learned in the workplace on employer attractiveness. The research findings indicated that 153 of the respondents stated that all five factors have a significant impact on employer attractiveness, ranked by the importance of each factor as follows, the most important listed first: Economic, Social, Development, Interest and Application.

The importance of this research lies in its being considered as an intermediate between two stages of the recruitment process; designing the plan and choosing the recruitment source, because it means that an organization that aims to recruit the best applicants must publish factual and honest information about the working conditions and benefits granted to employees, together with other information designed to attract the required competences.

The extent of the impact of the recruitment process on an organization differs according to the recruitment resources used. Some researchers consider that there are three recruitment resources: internal recruitment, external recruitment, and walk-in (Wanous, 1992), while other researchers (Hunter \& Schmidt, 1990) have described how the recruitment resources themselves may be formal or informal. Whatever the source of recruitment, the goal is to increase the attractiveness of the organization as an employer by communicating with potential applicants through the message reaching them from a particular source and an effective communication channel (Barber, 1998).

\subsection{Internal Sources}

Internal recruitment resources are preferred by organizations because they allow the organization to fill a vacancy from a known pool of employees and because these resources are under the organization's control 
(Hoye \& Lievens, 2005). One of the internal recruitment resources is job postings, a form of recruitment advertising (Kotler \& Keller, 2000) that can be defined as any internal announcement by an organization. Employees are considered as a wide pool for job vacancies in an organization. Internal job postings require issuing a circular regarding these vacancies for all employees in the organization, which provides an opportunity for employees who have the necessary efficiency, capabilities, and competences to apply for the vacancies (Haroon, 2010; Torrington et al., 2009).

Employee referrals are an internal channel for recruiting highly-skilled employees. Large organizations now depend increasingly on their employees to recruit specific candidates for job openings. Employee referrals are also the easiest source of recruitment because they do not require rigor on the part of the organization and the onus is on relatives and friends (Kugler, 1997).

According to Nicu and Sturz (2008) and Noe et al. (2008), the personal recruitment inside organizations offers a number of advantages, such as the following:

- The organization has complete information about candidates, which enables HR to assess each one based on his or her strengths and weaknesses. The advantage of this format is that it can belong to the activity of recruitment and of selection, according to the current researcher's belief. Its greatest advantage is that the applicants are well known to the organization (Noe et al., 2008).

- It is easier to attract candidates because they are better known. However, this mixes HRM activities when proposing advantages for using internal recruitment resources because better known candidate can be target by external sources (Nicu \& Sturz, 2008). However, other authors are more specific when addressing the advantages of internal recruitment resources for the recruitment process itself. In this regard, the following have been added to the previous advantages (Noe et al., 2008).

- The applicants are relatively knowledgeable about the organization's vacancies.

- Using internal resources to fill vacancies is cheaper and faster than using external resources. Meanwhile, it has been pointed out that the main advantage of using employee referrals is that an existing employee, through providing knowledge about the organization to the targeted person, could attract a strong candidate (Robbins \& Coulter, 2005).

At the same time, using internal recruitment resources as a policy could result in the following disadvantages: recruiting from inside an organization stops the infusion of new blood and limits the number of new applications (Linnehan \& Blau, 2003). This could also lead to a reduction in new ideas from outside the business and may decrease the diversity of employees (Tipper, 2004).

\subsection{External Sources of Recruitment}

According to one study (Fisher et al., 1993), the formal methods of external recruitment include newspaper, magazine and journal advertising, in addition to using employment agencies and, in the current era, job/career fairs and e-recruitment. External recruitment sources are not under the control of the organization, as job seekers can obtain information from external sources, such as word of mouth, and publicity. Publicity is an external source of information related to the recruitment process (Collins \& Steven, 2002), while Van Hoye and Lievens (2006) define word of mouth as the exchange of information through conversation between friends and relatives or from college instructors, although such information may include negative and positive aspects.

Regardless of which resource is used, in many situations there is a good case for using different methods in combination when looking to fill the same vacancy (Torrington et al., 2009). Research conducted to measure the relationship between the different sources of recruitment and the innovative abilities of employees at work by Conrad and Ashworth (1986) reported the survival rates in jobs arranged by the recruitment sources used with the following results: employee referrals (61.25\%), employment agencies (48.4\%), advertisements $(44.8 \%)$, and walk-ins $(58.4 \%)$. Another research has reached to the following results in terms of survival rates in jobs were that referrals are more effective than advertisements, referrals are better than agencies, referrals and walk-ins are of equal reliability, walk-ins are better than advertisements, and walk-ins are also better than agencies.

\subsection{Employees Training and Development}

This research has taken training and development as a part of HR practices by discussing those two practices broadly. On the other hand, the research will measure the effect of training on the organization. The research tackles the industrial organizations in Jordan and how they apply training methods as significant activity in HR.

Today business organizations are working within a dynamic and turbulent environment, which characterized by globalization, open markets, huge information loads and easy communication. These characteristics make it a 
'heavier' competitive business environment that requires organizations to compete effectively in the market place. Such purpose leads the organizations to think deeply in creating a systematic approach which enables it accomplish its strategic objectives. To help the managers in designing the business strategy, questions such as the following have to be answered:

- How do we compete in the market place?

- What do we need to differentiate our organization from others?

- What abilities and capabilities are required to achieve our organizational goals?

For the purposes of this study, focusing on inculcating a culture of customer focus in the hearts of employees of Jordanian industrial organizations as a result of training that will be represented by achieving customer satisfaction through the employees.

Employees training and development are from the human resource management activities, which, if they are linked to the strategic objectives of the organization, contribute effectively to the achievement of these objectives. In this regard, the literature indicated that, convinced of the director, that the workers have a larger role in achieving the goals of the organization and this conviction must be translated to plans, policies and practices (Holbeche \& Park, 2009). Such plans and policies would include: the quality of the employees to be hired, and how to strengthen their capacities and competencies through training and motivating them to work. When this happens, it will meet with more dedication to work by employees to achieve the goals of the organization, through which the employees' personal goals are achieved. Furthermore, motivated employees will realize that customer service is the reason for their presence in the organization. Goal such, customer focus is the point d'appui for other strategic organizational activities such as; quality control, pricing, human resources management, and production management and etc. to accomplish total quality management (TQM).

\section{Literature Review}

\subsection{Study by (Al Hamed, 2002)}

"The impact of incentives on the enhancements of the performance of employees in Jordanian public and private hospitals"

The study aimed to evaluate the impact of incentives on enhancing the performance in Jordanian public and private hospitals in the middle region through the ideal employment of the concept by the hospitals' administration. The study sample comprised four public hospitals, and five private hospitals, and the sample included 430 individuals, about $14 \%$ of the number of workers working in the private and public hospitals sectors in the middle region of Jordan. When distributing the sample all the various professions in these hospitals were taken into consideration, as per statistical rules. This study concluded the following: There are several differences in the way incentives affected the enhancement of performance among workers in Jordanian public and private hospitals, and disparity in the degree of impact of the how many people the incentives system includes on the performance of workers in public and private hospitals in Jordan. There are several differences in the way incentives affected the enhancement of performance among workers in Jordanian public and private hospitals. The results of the study also indicated that individual financial and moral incentives have a positive impact on the performance of workers in public and private hospitals in the middle region of Jordan.

\subsection{Study by (Al Shidi, 2001)}

"The Impact of Incentive of Job Satisfaction-A Study on the tendency of employees in the Administrative Units in the Sultanate of Oman"

The study aimed to identify the incentive system currently employed in the Sultanate of Oman, and their consistency with the job status, and study it, and identifying the other incentives that the employees wish to obtain, and the various technologies for all administrative levels, by studying the theoretical and applicable aspects of the incentives. The study community included all the employees in the administrative units in the Sultanate of Oman, and a sample was chosen for the study from the employees at various job levels stipulated in the Service Law. The study concluded that the major outcomes were:

There is a medium level of disparity regarding the financial incentives in the Public Service Law. There is a high degree of satisfaction regarding the moral incentives. The study recommends the following: 
- The importance of reconsidering the incentives relevant to the salaries of government employees.

- Work on undertaking various training courses and linking their outcomes with the relevant incentives scales.

- Work on sustaining incentives.

- Identify the individual and group incentives on job satisfaction.

\subsection{A Study by (Al Suheimat, 2002)}

"The Efficiency of the Incentives System of the Government and Private Sectors in Jordan, the status of several Government and Private organizations in the Governorate of Karak for the period 1990-2002"

The study aimed of to identify the weaknesses and shortcomings of the incentives systems applied in the various administrations in Jordan, and how efficient they are, and how they affect performance and the enhancement of productivity. The results were as follows:

First: There are differences of statistical significance in the prioritizing the weakness of the work incentives and the degree of job satisfaction among the study sample toward this, as was previously mentioned in descending order:

- Financial and moral incentives, the degree of satisfaction about these were from medium to weak.

- Job relation incentives, the degree of satisfaction about them was from medium to weak.

- Administrative and location work environment incentives, the degree of satisfaction about them was from medium to weak.

Whereas the degree of satisfaction regarding incentives relevant to the nature of the work, and its contents, was high.

Second: There are statistically significant differences in the replies of the study sample regarding the dimensions of the incentives and their efficiency are attributed to the work sector variable (government, public organizations, private organization), compared to each other, whereby the advantages were for the government sector. Third: there is a positive relationship between the interests of the sample in financial incentives, and the increase in the growth and development of society. The relationship was obvious from the status of the financial incentives that came in first place.

The study recommended the following: set a unified comprehensive salary system for workers in all private and public sectors consistent with the requirements of ensuring a dignified life.

- Enhance the umbrella of the Civil Service Bureau to include all the various work sectors in the public and private sector, to include a flexible and comprehensive incentives system that includes all kinds of incentives based on clear and accurate criteria and basics through which the incentives are granted objectively based on performance.

6.4 A Study by (Halaseh, 2006)

"The tendency of managers towards effective leadership training programs in Jordanian ministries during the period (2004-2005): Analytical Study"

This study aimed to identify the managers' tendencies towards the efficacy of leadership programs in Jordanian ministries. The study reached the following results:

There is a statistically significant relationship between the components of training program and the efficacy of these programs. There is a difference in the tendency of managers towards training program based on the variables of age, educational qualification, the administrative level, and the number of years of professional experience. 


\section{Statistical Analysis}

7.1 Sample's Characteristics

1) Gender

Table 1. Results of the sample's individuals' distribution according to the gender variable

\begin{tabular}{ccc}
\hline Gender & Frequency & Percentage \\
\hline Male & 78 & $78.0 \%$ \\
Female & 22 & $22.0 \%$ \\
Total & 100 & $100.0 \%$ \\
\hline
\end{tabular}

We notice the $78 \%$ of the sample are males.

2) Age

Table 2. Result of the sample's individuals' distribution according to the age variable

\begin{tabular}{ccc}
\hline Age & Frequency & Percentage \\
\hline Less than 25 years & 39 & $39 \%$ \\
$25-34$ years & 41 & $41 \%$ \\
$35-44$ years & 10 & $10 \%$ \\
45 years and more & 10 & $10 \%$ \\
Total & $\mathbf{1 0 0}$ & $\mathbf{1 0 0 \%}$ \\
\hline
\end{tabular}

We notice that $41 \%$ of the sample is of age $25-31$ and $39 \%$ are under 25 years old. The rest are over 35

3) Educational Qualification

Table 3. Results of the sample's individual's distribution according to the educational qualification variable

\begin{tabular}{ccc}
\hline Educational Qualification & Frequency & Percentage \\
\hline High School or less & - & - \\
Middle diploma & 21 & $21.0 \%$ \\
Bachelors & 76 & $76.0 \%$ \\
Higher Education & 3 & $3.0 \%$ \\
Total & 100 & $100.0 \%$ \\
\hline
\end{tabular}

We notice that $76 \%$ carry a bachelor's degree, followed by the middle diploma carriers which show that the highest percentage of the sample are university degrees carriers.

4) Management Level

Table 4. Results of the distribution of the sample individuals based on management level variable

\begin{tabular}{ccc}
\hline Career Level & Frequency & Percentage \\
\hline Executive Management & 58 & $58 \%$ \\
Middle Management & 35 & $35 \%$ \\
Higher Management & 7 & $7 \%$ \\
Total & $\mathbf{1 0 0}$ & $\mathbf{1 0 0 \%}$ \\
\hline
\end{tabular}


We have noted that $58 \%$ of the sample is of the executive management level, followed by the middle management and then the higher one.

5) Professional Experience

Table 5. Results of the sample distribution according to the experience variable

\begin{tabular}{ccc}
\hline Experience & Frequency & Percent \\
\hline Less than 5 years & 33 & $33 \%$ \\
$5-10$ years & 45 & $45 \%$ \\
$11-15$ years & 16 & $16 \%$ \\
$16-20$ years & 6 & $6 \%$ \\
More than 20 years & - & - \\
Total & $\mathbf{1 0 0}$ & $\mathbf{1 0 0 \%}$ \\
\hline
\end{tabular}

We noted that $33 \%$ of the sample have less than 5 years experience and $16 \%$ have between $11-15$ years, whereas $45 \%$ have between 5-10 years and the rest have more than 15 years of experience.

\section{Study Results}

The median and standard deviation for the answers was calculated as shown below:

Table 6. The median and standard deviation for the study

\begin{tabular}{|c|c|c|}
\hline Paragraph & Standard Deviation & Mean \\
\hline \multicolumn{3}{|l|}{ Choice } \\
\hline $\begin{array}{l}\text { 1. The company uses internal hiring policy for people with educational and } \\
\text { professional competencies, in addition to developing unique efforts. }\end{array}$ & 0.52522 & 4.3700 \\
\hline $\begin{array}{l}\text { 2. The company's policy embodies career security which deepens the loyalty spirit } \\
\text { amongst its employees. }\end{array}$ & 0.57525 & 4.1800 \\
\hline 3. Creative experience is a key factor in hiring the company's personnel. & 0.58913 & 4.4200 \\
\hline \multicolumn{3}{|l|}{ Attracting } \\
\hline $\begin{array}{l}\text { 4. The company is based on the attempt on attracting and choosing human resources } \\
\text { that are able to accomplish the company's goals }\end{array}$ & 0.63596 & 4.4100 \\
\hline $\begin{array}{l}\text { 5. The company is based on following competent labor and it works on employing } \\
\text { such competencies. }\end{array}$ & 0.71661 & 4.5400 \\
\hline \multicolumn{3}{|l|}{ Motivation: } \\
\hline $\begin{array}{l}\text { 6. The company adapts compensation policy based on that pay is controlled by } \\
\text { knowledge. }\end{array}$ & 0.64354 & 4.1000 \\
\hline 7. The management is interested in offering creative employees financial incentives. & 0.65713 & 4.0500 \\
\hline $\begin{array}{l}\text { 8. The company offers its personnel good financial incentives in line with the } \\
\text { performance level. }\end{array}$ & 0.79258 & 4.0900 \\
\hline \multicolumn{3}{|l|}{ Training: } \\
\hline 9. The company encourages training methods that enhances self teaching. & 0.85257 & 3.9800 \\
\hline 10. In general, the employees are always ready for continuous learning. & 0.78650 & 4.2600 \\
\hline 11. The company adapts total quality management in the training plans. & 0.63532 & 4.0200 \\
\hline $\begin{array}{l}\text { 12. The training courses of the company has modern technology based on self study } \\
\text { electronic learning, }\end{array}$ & 0.75371 & 4.2400 \\
\hline $\begin{array}{l}\text { 13. The training plans in the company are based on interaction between employees to } \\
\text { enhance their knowledge. }\end{array}$ & 0.75338 & 4.0900 \\
\hline
\end{tabular}




\section{Appointing:}

14. Employees' appointment is based on experience and competencies that have a role in creating a competitive advantage.

15. Setting employment policies that are related to the company's goals has a role in creating a competitive advantage.

16. Periodic studies related to hiring needs are undertaken by the company in order to fulfill these needs.

0.757120

0.645970

0.552220

0.701800

4.1800

17. Periodic evaluation for the personnel's performance has a role in obtaining a competitive advantage.

18. Advising the employees regarding the evaluation results has a role in obtaining a competitive advantage.

19. Linking the evaluation results to career progress results has a role in obtaining a competitive advantage.

20. Linking the evaluation with the performance and incentives has a role in obtaining a competitive advantage.

21. Periodic performance evaluation based on supported foundations has a role in obtaining a competitive advantage.

22. Setting and executing an efficient increments system has a role in obtaining a competitive advantage.

23.Continuous improvement for the increments system and benefits from time to time has a role in obtaining a competitive advantage.

24.Insuring the balance of the increments by periodic studies system has a role in obtaining a competitive advantage.

25.The employee's knowledge with the grounds of bonuses has a role in obtaining a competitive advantage.

26.Promoting the employee based on fair foundations has a role in obtaining a competitive advantage

27.Moral increments (letters of appreciation, moral support.) have a role in obtaining a competitive advantage.

\section{Competitive Advantage:}

28.There is a noted increase in the company's sales.

29.The company's market share is growing

30.The company is known for high quality products.

31.The company responds to the technological development.
0.846860

4.1000

0.790350

4.0400

0.694200

4.2700

0.717110

4.5300

4.2600

3.9200

3.9100

3.8900

4.2500

4.0000

4.2400

4.0600

0.790030

We notice that the sample's orientations regarding the paragraphs above are positive since their mean value is greater than the average measurement tool which is 3 .

\section{Results' Discussion}

Results of statistical analysis of the data indicated that the sample companies apply strategies to recruit staff based on multiple sources and methods of recruitment, thereby, helping to attract the best applicants, where the mean of using internal sources amounted to 4.37 and 4.42 for using external sources, and this means the prove of the first hypothesis which is "There is statistically significant relationship between recruitment strategy and attracting best applicants". Also, the results showed that questions 14 and 15 where devoted to the importance of skills, competencies and experience in order to enable the staff to achieve competitive advantage, and this means the prove of the second hypothesis which is "There is statistically relationship between the availability of talent, competencies and qualifications in the recruited employees and achieving competitive advantage".

In order to develop the employees performance and behavior, most of the sample companies, engaged in training as a tool for developing the performance and behavior of the employees, where questions from No. 9 to No. 13 
where devoted to the training activity. The mean for these questions amounted to 4.118 and standard deviation of 0.757 which means approve the third hypothesis which is "There is statistically relationship between training programs and methods, and employee's development to create competitive advantage". Also, the fourth hypothesis was in the case of prove, where the lowest mean was for question No. 23 (3.89), which is greater than the average measurement tool which is 3 .

Therefore, we can say that organizations can achieve competitive advantage through the staff that are talented and have appropriate skills and experiences.

\section{Recommendations}

The researchers present the following recommendations: companies must focus on improving the methods used by them to recruit candidates. And they have to stop using recruitment methods which allow intervention of nepotism and cronyism in the employment process, such as newspaper advertising. Also, companies must view employees training as a way to enhance the employees' abilities and improve performance and enable them to provide new ideas that may differentiate their organization from rivals.

\section{References}

Al Hamid, G. (2002). The Impact of insentives on the Inhansement of the Performance of Employees in Jordanian Public and Private Hospitals. A Thesis for Master Degree, Alnilein University, Sudan.

Al Shidi, M. B. Q. (2001). The Impact of Insentives of Job Satisfaction-Astudy on tendency of employees in the Aministrative Units in the Sultinate of Oman. Al Albeit University, Jordan.

Al Suheimat, Y. (2002). The Efficiency of the Insentives System of the Government and Private Sectors in Jordan, The Status of Several Government and Private Organizations in the Governerate of Karak for the Period 1990-2000. B.H.D Thesis, Alsudan University for Science and Technology.

Backhaus, K., \& Tikoo, S. (2004). Conceptualizing and Researching, Employer Branding. Career Development International, 9(5), 501-517. http://dx.doi.org/10.1108/13620430410550754

Barber, A. (1998). Recruiting Employees: Individual and Organizational Perspectives. Thousand Oaks, CA: Sage.

Barney, J., \& Wright, P. (1997). On Becoming a Strategic Partner: The Role of Human Resources in gaining competitive Advantage. Cornell University, Center for Advanced Human Resource Studies. Retrieved from www.vocabulary.com/dictionary/talent.

Berthon, P., Ewing, M., \& Hah, L. L. (2005). Captivating company: Dimensions of Attractiveness in employer branding. International Journal of Advertising, 24(2), 151-172.

Breaugh, J. A. (2008). Employee Recruitment Current Knowledge and Important Areas for Future Research. Human Resource Management Review, 18(3), 103-118. http://dx.doi.org/10.1016/j.hrmr.2008.07.003

Breaugh, J., \& Starke, M. (2000). Research on Employee Recruitment: So Many Studies, so Many Remaining Questions. Journal of Management, 26(3), 405-434. http://dx.doi.org/10.1177/014920630002600303

Carroll, M., Marchington, M., Earnshaw, J., \& Taylor, S. (1999). Recruitment in small firms: Processes, methods and problems. Employee Relation, 21(3), 236-250. http://dx.doi.org/10.1108/01425459910273080

Cascio, W. F. (2003). Changes in Workers, Work, and Organisations. In D. R. Ilgen, U. W. Borman, \& R. J. Klimoski (Eds.), Handbook of Psychology:Industrial and Organizational Psychology (Vol. 12, pp. 399-422). Hoboken, NJ: Wiley \& Sons. http://dx.doi.org/10.1002/0471264385.wei1216

Collins, C. J., \& Steven, C. (2002). The Relationship Between Early Recruitment-Related Activities and the Application Decisions of New Labour-Market entrants: A Brand Equity approach to Recruitment. Journal of Applied Psychology, 87(6), 1121-1133. http://dx.doi.org/10.1037/0021-9010.87.6.1121

Conrad, M. A., \& Ashworth, S. D. (1986). Recruiting Source Effectiveness: A Meta-Analysis and Re-examination of Two Rival Hypotheses. Paper Presented At The First Annual Meeting of the Social for Industrial and Organizational Psychology. Chicago: IL.

Croy, G., \& Duggan, B. (2005). The Recruitment Debate: To outsource or not to outsource? Which is the bigger risk? Human Resource Management International Digest, 13(3), 27-29. http://dx.doi.org/10.1108/09670730510595012 
Delaney, J. T., \& Huselid, M. A. (1996). The Impact of Human Resource Management Practices on Performance in for-Profit and Nonprofit Organizations. Academy of Management Journal, 39(4), 949-969. http://dx.doi.org/10.2307/256718

Ehrenberg, R. G., \& Smith, R. S. (2002). Modern Labour Economic: Theory and Public Policy (8th ed.). Reading, Mass: Addison Wesley.

Fisher, C., Schoenfeldt, L. E., \& Shaw, J. B. (1993). Human Resource Management (2nd ed.). Boston: Houghton Mifflin.

Haroon, M. (2010). Determination of Relative Effective Recruitment Sources. A case Based on experience of Pakistani Banks. Interdisciplinary Journal of Contemporary Research in Business, 1(11). Retrieved from http://news-business.vlex.co.uk/vid/recruitment-case-based-pakistani-banks-229205815

Hatch, N., \& Dyer, J. (2004). Human Capital and Learning as A Source of Sustainable competitive Advantage. Strategic Management Journal, 25, 1155-1178. http://dx.doi.org/10.1002/smj.421

Hoye, G. V., \& Lievens, F. (2006). Tapping and Grapevine: A Closer Look at Word-of-Mouth as a Recruitment source. Journal of Applied Psychology, 92(2), 341-352.

Hoye, G., \& Lievens, F. (2005). Recruitment Related Information Sources and Orgnisational Attractiveness: Can Something Be Done about Negative Publicity? International Jouirnal of Selection and Assessment, 13(3).

Hunter, J. E., \& Schmidt, F. L. (1990). Methods of Meta-Analysis: Correcting Error and Bias in Research Findings. Newbury Park, CA: Sage.

Huselid, M., \& Becker, B. (2011). Bridging Micro and Macro Domains: Workforce Differentiation and Strategic Human Resource Management. Journal of Management, 37(2), 421-428. http://dx.doi.org/10.1177/0149206310373400

Knowles, J. A., Parlier, G. H., \& Hoscheit, G. C. (2002). Reinventing Army Recruiting. Interfaces, 32(1), 78-92. http://dx.doi.org/10.1287/inte.32.1.78.17

Kotler, P., \& Keller, K. L. (2000). Marketing Management (The Millennium ed.). Upper Saddle Rive, NJ: Pearson Prentice Hall.

Kugler, A. (1997). Employee Referrals and the Inter-Industry Wage Structure. Journal of Economic Literature Classification, 1-59. Retrieved from http://repositori.upf.edu/handle/10230/1091

Lewis, W. J., Van Lenteren, J. C., Phatak, S. C., \& Tumlinson, J. H. (1997). A Total System Approach to Sustainable Pest Management. Journal List 7 Proc Acad Sc, 94(23), 12243-12248. http://dx.doi.org/10.1073/pnas.94.23.12243

Linnehan, F., \& Blau, G. (2003). Testing the Impact of Job search and Recruitment Source on New Hire Turnover in Maquila Dora. Journal of Applied Psychology, 52(2), 553-562. http://dx.doi.org/10.1111/1464-0597.00134

Lloyds, S. (2002). Branding From The Inside Out. BRW Magazine, 32(10), 64-66.

Lockwood, N. R. (2007). Leveraging Employee Engagement for Competitive Advantage. Research Quarterly, $52(3), 1-12$.

Mayer, R. C., \& Davis, J. H. (1999). The effect of the performance appraisal system on trust for management: A field quasi-experiment. Journal of Applied Psychology, 84(1), 123-136. http://dx.doi.org/10.1037/0021-9010.84.1.123

Michelson, G., \& Kramar, R. (2003). The State of HRM in Australia: Progress and Prospects. Asia Pacific Journal of Human Resources, 41(2), 133-148. http://dx.doi.org/10.1177/10384111030412002

Morse, B. J., \& Popovich, P. M. (2009). Realistic Recruitment Practices in Organisations: The Potential Benefits of Generalized Expectancy Calibration. Human Resource Management Review, 19(1), 1-8. http://dx.doi.org/10.1016/j.hrmr.2008.09.002

Nicu, S., \& Sturz, A. (2008). The Advantages and Disadvantages of Personnel Recruitment Intern Source. Romania: University "Aurel Vlaicu” of Arad.

Nijssen, E. J., Hillebrand, B., Vermeulen, P. A. M., \& Kemp, R. G. M. (2006). Exploring Product and Service Innovation Similarities and Differences. International Journal of Research in Marketing, 23, 241-251. http://dx.doi.org/10.1016/j.jiresmar.2006.02.001 
Noe, R. (2010). Employee Training \& Development (5th ed.). New York: Mc Graw-Hill.

Noe, R., Hollenbeck, J. R., Gerhart, B., \& Wright, P. M. (2008). Human Resource Management: Gaining a Competitive Advantage. New York: McGraw-Hill.

Robbins, S. P., \& Coulter, M. K. (2005). Management (8th ed.). Upper Saddle River, NJ: Prentice Hall.

Ryan, A. M., \& Tippins, N. T. (2004). Attracting and Selecting: What Psychological Research Tells Us. Human Resource Management, 43 (4), 305-318. http://dx.doi.org/10.1002/hrm.20026

Rynes, S. L., \& Barber, A. E. (1990). Applicant Attraction Strategies: An Organisational Perspective. Academy of Management Review, 15, 286-310.

Sackett, P. R., Schmitt, N., Ellingson, J. E., \& Kabin, M. B. (2001). High Stakes Testing in Employment, Credentialing, and Higher Education: Prospects in a post-Affirmative Action World. American Psychologist, 56(4), 302-318. http://dx.doi.org/10.1037/0003-066X.56.4.302

Sheehan, C., \& Scafidi, A. (2005). The Strategic Role of HR managers in Australian Organisations: Cues From Organisational Recruitment Sources. Journal of the Australian and New Zealand Academy of Management, 11(1), 41-56.

Singh, P., \& Finn, D. (2003). The Effects of Information Technology on Recruitment. Journal of Labour Research, 24(3), 395-408. http://dx.doi.org/10.1007/s12122-003-1003-4

Thompson, L., \& Aspinwall, K. (2009). The Recruitment Value of Work/Life Benefits. Personnel Review, 38(2), 195-210. http://dx.doi.org/10.1108/00483480910931343

Tipper, T. (2004). How to increase diversity through your recruitment practices. Industrial and Commercial Training , 35(4), 158-161. http://dx.doi.org/10.1108/00197850410542392

Torrington, D., Hall, L., \& Taylor, S. (2009). Fundamentals of Human Resource Management (illustrated ed.). Harlow: Prentice Hall.

Townsend, K. (2007). Recruitment, Training and Turnover: Another Call Center paradox. Personnel Review, 36(3), 476-490. http://dx.doi.org/10.1108/00483480710731383

Wanous, J. (1992). Organisational Entry. Reading, Massachusetts: Addison-Wesley Publishing Company.

Zottoli, M. A., \& Wanous, J. P. (2000). Recruitment Source Research: Current Status and Future Directions. Human Resource Management Review, 10(4), 353-382. http://dx.doi.org/10.1016/S1053-4822(00)00032-2

\section{Appendix A.}

\section{Research Questionnaire}

\section{Part One: Demographic and Career Characteristics:}

Please put $(\checkmark)$ where applicable:

$\begin{array}{lll}\text { Gender: } & \square \text { Male } & \square \text { Female } \\ \text { Age: } & \square \text { Less than } 25 & \square 25-34 \text { years } \\ & \square 35-44 \text { years } & \square 45 \text { and more }\end{array}$

Educational Qualification: $\square$ High School or less $\quad \square$ Middle Diploma

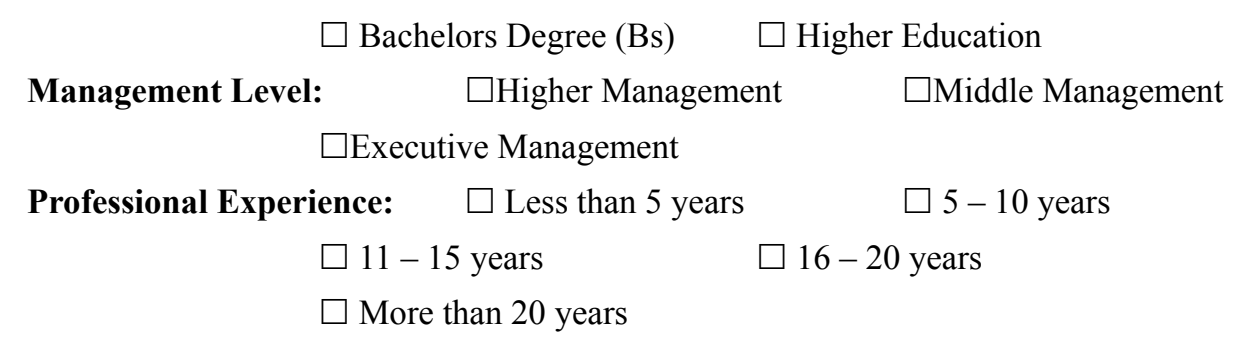


Part two: Please put $(x)$ in the box of the closest answer in your entity:

\begin{tabular}{|c|c|c|c|c|c|}
\hline Paragraph & $\begin{array}{l}\text { Strongly } \\
\text { Agree }\end{array}$ & Agree & Neutral & Disagree & $\begin{array}{l}\text { Strongly } \\
\text { Disagree }\end{array}$ \\
\hline
\end{tabular}

\section{Choice}

1- The company uses internal hiring policy for people with educational and professional competencies, in addition to developing unique efforts.

2- The company's policy embodies career security which deepens the loyalty spirit amongst its employees.

3- Creative experience is a key factor in hiring the company's personnel.

\section{Attracting}

4- The company is based on the attempt on attracting and choosing human resources that are able to accomplish the company's goals

5- The company is based on following competent labor and it works on employing such competencies.

\section{Motivation:}

6- The company adapts compensation policy based on that pay is controlled by knowledge.

7- The management is interested in offering creative employees financial incentives.

8- The company offers its personnel good financial incentives in line with the performance level.

\section{Training:}

9- The company encourages training methods that enhances self teaching.

10 -In general, the employees are always ready for continuous learning.

11-The company adapts total quality management in the training plans.

12-The training courses of the company has modern technology based on self study electronic learning,

13- The training plans in the company are based on interaction between employees to enhance their knowledge. 


\section{Appointing:}

14-Employees' appointment is based on experience and competencies that have a role in creating a competitive advantage.

15-Setting employment policies that are related to the company's goals has a role in creating a competitive advantage.

16-Periodic studies related to hiring needs are undertaken by the company in order to fulfill these needs.

\section{Evaluation:}

17-Periodic evaluation for the personnel's performance has a role in obtaining a competitive advantage.

18-Advising the employees regarding the evaluation results has a role in obtaining a competitive advantage.

19-Linking the evaluation results to career progress results has a role in obtaining a competitive advantage.

20-Linking the evaluation with the performance and incentives has a role in obtaining a competitive advantage.

21-Periodic performance evaluation based on supported foundations has a role in obtaining a competitive advantage.

\section{Setting salaries, bonuses and incentives:}

22-Setting and executing an efficient increments system has a role in obtaining a competitive advantage.

23-Continuous improvement for the increments system and benefits from time to time has a role in obtaining a competitive advantage.

24-Insuring the balance of the increments by periodic studies system has a role in obtaining a competitive advantage.

25-The employee's knowledge with the grounds of bonuses has a role in obtaining a competitive advantage.

26-Promoting the employee based on fair foundations has a role in obtaining a competitive advantage

27-Moral increments (letters of appreciation, moral support.) have a role in obtaining a competitive advantage. 
Part Three: Competitive Advantage:

Please put $(\checkmark)$ where you agree.

\begin{tabular}{lccccc}
\hline Paragraph & $\begin{array}{c}\text { Strongly } \\
\text { Agree }\end{array}$ & Agree & Neutral & Disagree & $\begin{array}{c}\text { Strongly } \\
\text { Disagree }\end{array}$ \\
\hline
\end{tabular}

1. There is a noted increase in the company's sales.

2. The company's market share is growing

3. The company is known for high quality products.

4. The company responds to the technological development.

\section{Copyrights}

Copyright for this article is retained by the author(s), with first publication rights granted to the journal.

This is an open-access article distributed under the terms and conditions of the Creative Commons Attribution license (http://creativecommons.org/licenses/by/3.0/). 